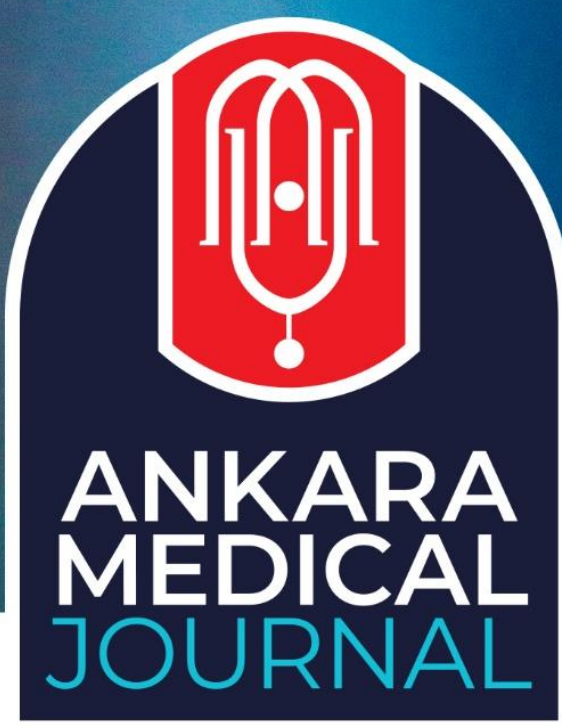

Research Article

Ankara Med J, 2021;(1):115-123 // 10 10.5505/amj.2021.73693

\title{
TEMPOROMANDIBULAR JOINT DISLOCATION AT THE EMERGENCY DEPARTMENT: A RETROSPECTIVE STUDY
}

\section{ACİL SERVİ'TE TEMPOROMANDİBULAR EKLEM DISSLOKASYONU: GERIYYE DÖNÜK BİR ÇALIŞMA}

(D) Filiz Baloglu Kaya1, (D) Engin Özakin1, (D) Seyhmus Kaya²,

(i) Muhammed Evvah Karakilic ${ }^{1}$

${ }^{1}$ Eskisehir Osmangazi University Faculty of Medicine and Health Science, Department of Emergency Medicine, Eskisehir.

${ }^{2}$ Eskisehir City Hospital Department of Emergency Medicine

Yazışma Adresi / Correspondence:

Dr. Öğr. Üyesi Filiz Baloglu Kaya (e-mail: xxxxxxx@gmail.com)

Geliş Tarihi (Submitted): 24.12.2020 // Kabul Tarihi (Accepted): 02.03.2021

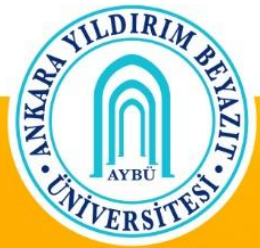

Ankara YIldırım Beyazıt University Faculty of Medicine

Department of Family Medicine 


\section{Öz}

Amaç: $\mathrm{Bu}$ çalışmanın amacı, acil serviste (AS) Temporomandibular eklem (TME) dislokasyonu tanısı alan olguların demografik ve klinik özelliklerini hasta idaresi ile birlikte değerlendirmektir.

Materyal ve Metot: Çalışmamız tek merkezli ve geriye dönük olarak 10 yıl ve 10 aylık bir sürede (01.01.2010 30.10.2020) Eskişehir Osmangazi Üniversitesi Sağlık, Uygulama ve Araştırma Hastanesi Acil Servis'inde yapılmıștır. Çalışma sürecinde AS'ye başvuran, TME dislokasyonu tanısı alan, 18 yaş ve üzeri tüm hastalar çalışmaya dahil edilmiştir. Olguların demografik verileri, dislokasyon tipi ve mekanizması, tekrarlayan dislokasyon hikayesi varlığı, görüntüleme varlığı, redüksiyon uygulaması varlığı, yapıldı ise redüksiyon sonlanımı ve sedoanaljezi gerekliliği ile ilgili bilgileri dosya kayıtlarından alınmıştır. Analiz için gerekli verilere kayıtlarda ulaşılamaması da dışlama kriteri olarak belirlenmiştir.

Bulgular: Dosya kayıtları incelendiğinde 113 olgunun AS'de TME dislokasyonu tanısı aldığı görüldü. 66 olgu birincil başvuru, 47 olgu ise bu olguların tekrarlayan başvuruları idi. Birincil başvurular değerlendirildiğinde; yaş ortalaması 42,74 $\pm 20,83$ idi ve \%69,7'si (n=46) kadındı. \%56,1 (n=37) bilateral eklem dislokasyonu mevcuttu. \%98,5'i (n=65) non-travmatik idi. Olguların tamamına bakıldığında \%91,2'sinde (n=103) radyolojik görüntüleme yapılmadığı belirlendi. Redüksiyon işlemleri sırasında \%13,3 (n= 15) olguda sedoanaljezi uygulandığı görüldü. Redüksiyon uygulamalarının \%98,2'sinin (n=111) başarı ile sonuçlandığı görüldü. Olgulara ait komplikasyon kaydına rastlanmadı.

Sonuç: TME dislokasyonu idaresi hasta konforu ile eklem fonksiyonu açısından önemlidir. Acil tıp hekimleri nadir de olsa karşılaştıkları akut TME dislokasyonu idaresini başarı ile gerçekleştirmektedirler.

Anahtar Kelimeler: Temporamandibular eklem, dislokasyon, redüksiyon.

\footnotetext{
Abstract

Objectives: This study aims to evaluate demographic and clinical characteristics of the emergency department (ED) cases with a diagnosis of temporomandibular joint (TMJ) dislocation alongside the patient management of these cases.

Materials and Methods: Our single-center and retrospective study was conducted at the ED of Eskisehir Osmangazi Health, Practice and Research Hospital in 10 years and 10 months (01.01.2010-30.10.2020). All 18 years and older patients diagnosed with TMJ dislocation at the ED during the studied period were included in the study. The information on demographics, dislocation type and mechanism, medical history of repeated dislocation, imaging, application of reduction, reduction outcome, and necessity of sedo-analgesia were obtained from the patients' records. The lack of data required for analysis in the records was taken as an exclusion criterion.

Results: When the file records were examined 113 cases were diagnosed with TMJ dislocation in ED. 66 cases were primary admissions and 47 cases were recurrent admissions of these cases. Primary applications are evaluated; the mean age was $42.74 \pm 20.83$ and $69.7 \%(n=46)$ were women. The joint dislocation was present in $56.1 \%(n=37)$ bilaterally. $98.5 \%(n=65)$ of them were non-traumatic. When all the cases were evaluated, it was determined that $91.2 \%(n=103)$ did not perform radiological imaging. During reduction, it was observed that sedo-analgesia was applied in $13.3 \%(n=15)$ cases. It was observed that $98.2 \%(n=111)$ of the reduction applications resulted successfully. No complication records of the cases were found.

Conclusion: Management of TMJ dislocation is important for patient comfort and joint function. Emergency physicians successfully manage acute TMJ dislocation, which they rarely encounter.

Keywords: Temporomandibular joint, dislocation, reduction.
} 


\section{Introduction}

The temporomandibular joint (TMJ) is between the mandible and the temporal bone and its movements are controlled by a neuromuscular system composed of the mastication muscles, the ligaments associated with the TMJ, and the mandibular division of the trigeminal nerve. ${ }^{1}$ TMJ dislocation is an infrequent condition, but it might cause serious functional loss. A threatened airway due to the inability to control secretions, difficulty in eating and speaking, and pain are the problems related to TMJ dislocation. It often occurs in relation to the extreme opening of the mouth in a spontaneous, iatrogenic, or traumatic way. Mandibular condyles might be displaced from the joint unilaterally or bilaterally. The joint might remain dislocated as a result of the ligament tension and muscle spasm, but in some cases, spontaneous recovery might also occur. ${ }^{2}$ The diagnosis is clinical, but the radiological evaluation is done in selective cases. Mostly the Emergency Department (ED) physicians encounter acute dislocation cases. The joint function is often restored with reduction at the ED and patients' pain was relieved.

This study aims to evaluate demographic and clinical characteristics of the ED cases with a diagnosis of TMJ dislocation alongside the patient management of these cases.

\section{Materials and Methods}

Our single-center and retrospective study was conducted at the ED of Eskisehir Osmangazi Health, Practice and Research Hospital in 10 years and 10 months (01.01.2010-30.10.2020). All 18 years and older patients diagnosed with TMJ dislocation at the ED during the studied period were included in the study.

The information on demographics, dislocation type and mechanism, medical history of repeated dislocation, imaging, application of reduction, reduction outcome (successful, complications, etc.), and necessity of sedoanalgesia for reduction were obtained from the patients' records. The lack of data required for analysis in the records was taken as an exclusion criterion.

\section{Statistical Analysis}

The categorical data were indicated as frequency and percentage (\%). The continuous variables were indicated as the means and SD. IBM SPSS Statistics 21.0 (IBM Corp. Released 2012. IBM SPSS Statistics for Windows, Version 21.0. Armonk, NY: IBM Corp.) was used for analysis. 


\section{Results}

Out of 676298,113 cases admitted to the ED during the studied period fulfilled the inclusion criteria. While 66 cases were primary admissions, 47 were recurring cases. Within the study duration, 1 case was readmitted 29 times, 1 case was readmitted 9 times, 1 case was readmitted 3 times, 2 cases were readmitted twice, and 2 cases were readmitted once to the ED. The primary admission of cases with multiple readmissions was taken into consideration in order to avoid any impact on the demographic data.

\section{Evaluation of the primary admissions}

The mean age of 66 cases detected as primary admissions was $42.74 \pm 20.83$ (range, 18-87) and the median age was $37.50(\mathrm{Q} 1-\mathrm{Q} 3=25-57) .69 .70 \%(\mathrm{n}=46)$ of all cases were female. Of all cases, 51.50\% ( $\mathrm{n}=34)$ had a history of previous TMJ dislocation. Regarding the position of dislocated joint, $56.10 \%$ ( $n=37$ ) was bilateral, $22.70 \%$ $(\mathrm{n}=15)$ was on the left side, and $21.20 \%(\mathrm{n}=14)$ was on the right side.

Considering the dislocation mechanisms, $98.50 \%(\mathrm{n}=65)$ occurred due to non-traumatic factors. Yawning was found as the most frequent trigger of dislocation as seen in $80.30 \%(n=53)$ of all cases. Of all cases, $86.40 \%$ did not require imaging during the ED evaluation. Only in 1 case with imaging, a fracture was detected alongside the dislocation. The ratio of successful reductions performed to treat the dislocations at the ED was $97.00 \%$ $(n=64)$. In 1 case with fracture-dislocation, the reduction was not performed. One case was referred to the related surgical clinic after the reduction was unsuccessful. Sedo-analgesia was administered in $21.21 \%$ $(n=14)$ of all cases during reduction (Table 1). No record of post-reduction complications was found.

\section{Co-evaluation of primary and recurring admissions}

During the studied period, 113 cases (66 primary and 47 recurring) were evaluated together. Regarding the dislocation mechanisms, the most common triggers in readmitted cases were eating with $55.31 \%(\mathrm{n}=26)$, yawning with $36.17 \%(n=17)$, and seizure with $8.51 \%(n=4)$. Of all cases, $91.20 \%(n=103)$ did not require radiologic imaging at the ED. While imaging was used in 9 primary admission cases, it was used only for 1 readmitted case. The ratio of successful reductions performed to treat the dislocations at the ED was $98.20 \%$ $(\mathrm{n}=111)$. In readmitted cases, the reduction was performed in all cases with a successful outcome. The evaluation of all cases revealed that sedo-analgesia was administered in $13.30 \%(n=15)$ of the cases during reductions. While 14 primary admission cases had sedo-analgesia, only 1 readmitted case had sedo-analgesia (Table 1). 
When we investigated our cases for additional diseases related to TMJ ligament or bone structure, or those which might affect the neurovascular functions of TMJ, we found Parkinson's disease only in 1 case.

Table 1. Dislocation mechanisms, imaging at the ED, and reductions in the cases

\begin{tabular}{|c|c|c|c|c|c|c|c|}
\hline \multicolumn{2}{|l|}{ Variable } & \multicolumn{2}{|c|}{$\begin{array}{c}\text { Primary } \\
\text { Admissions } \\
\text { n=66 (\%) }\end{array}$} & \multicolumn{2}{|c|}{$\begin{array}{c}\text { Readmissions } \\
\mathrm{n}=47(\%)\end{array}$} & \multicolumn{2}{|c|}{$\begin{array}{c}\text { All Admissions } \\
n=113(\%)\end{array}$} \\
\hline \multirow{9}{*}{ Mechanism } & Yawning & 53 & 80.30 & 17 & 36.17 & 70 & 61.90 \\
\hline & Seizure & 3 & 4.50 & 4 & 8.51 & 7 & 6.20 \\
\hline & Vomiting & 2 & 3.00 & - & - & 2 & 1.80 \\
\hline & Eating & 2 & 3.00 & 26 & 55.31 & 28 & 24.80 \\
\hline & Sclerosis/ Locked-in & 2 & 3.00 & - & - & 2 & 1.80 \\
\hline & Tooth extraction & 1 & 4.50 & - & - & 1 & 0.90 \\
\hline & Coughing & 1 & 4.50 & - & - & 1 & 0.90 \\
\hline & Speaking & 1 & 4.50 & - & - & 1 & 0.90 \\
\hline & Trauma & 1 & 4.50 & - & - & 1 & 0.90 \\
\hline \multirow{2}{*}{ Imaging } & Not-performed & 57 & 86.30 & 46 & 97.87 & 103 & 91.20 \\
\hline & Performed & 9 & 13.60 & 1 & 2.12 & 10 & 8.80 \\
\hline \multirow{3}{*}{$\begin{array}{l}\text { Reduction } \\
\text { outcome at the } \\
\text { ED }\end{array}$} & Successful & 64 & 96.90 & 47 & 100 & 111 & 98.20 \\
\hline & Unsuccessful & 1 & 1.50 & - & - & 1 & 0.90 \\
\hline & Not performed & 1 & 1.50 & - & - & 1 & 0.90 \\
\hline \multirow{2}{*}{ Sedo-analgesia } & Not-performed & 52 & 78.70 & 46 & 97.87 & 98 & 86.70 \\
\hline & Performed & 14 & 21.20 & 1 & 2.12 & 15 & 13.30 \\
\hline
\end{tabular}

\section{Discussion}

TMJ dislocation is a rare condition of the facial skeleton which might cause serious functional loss. Of all the dislocations of the body, the incidence rate for TMJ dislocation is about $3 \% .{ }^{3}$ Annual incidence rate associated with ED admissions is 5.3/1000000.4 Our study revealed that the TMJ dislocation cases comprised $0.016 \%$ of all ED admissions. This rate might be affected by the cases that did not consult with a physician after recovery due to subluxation or spontaneous reduction.

The average age of the cases in our study was 42.74 , similar to the numbers reported by other studies in the literature. 2,5 Of all cases $69.70 \%$ were female. The gender ratio in our study was parallel to the female predominance indicated and associated with hormonal qualities in the literature.5,6

The risk of recurrence in TMJ dislocation cases is a known fact. ${ }^{7,8}$ We did not encounter a recurrence rate in the literature, however, in our study, the history of previous dislocations in the primary admission cases was $51.50 \%$. The weak joint capsule, anatomical changes, and ligament damage increase the recurrence risk. Recurrence etiology of TMJ dislocations also comprises connective tissue disorders such as Ehlers-Danlos Syndrome and age-related joint degeneration and neurodegenerative diseases such as Parkinson's disease, 
which might cause muscular dystonia. ${ }^{9-11}$ In our study, one case with 29 readmissions at the ED was found compatible with the information in the literature considering the patient's old age and Parkinson's disease. We did not find a risk factor in the medical history of other readmitted cases. The relation between the female gender and recurrence was also indicated in the literature. ${ }^{9}$ In our study, it was detected that 47 readmissions belonged to 7 cases and 5 of these cases were female.

TMJ dislocations are often bilateral with an open, symmetrical, and fixed jawbone. The incidence rate of bilateral dislocation was indicated as $59.40 \%$ in a retrospective study similar to ours. ${ }^{2}$ Even though the incidence ratio is lower, unilateral dislocations are also seen presenting a deviated jaw towards the unaffected side. ${ }^{12}$ The literature did not present precise numbers in this issue, but we detected $22.70 \%$ left-sided and $21.20 \%$ right-sided dislocations among our cases.

TMJ dislocations can be categorized as spontaneous, iatrogenic, and traumatic regarding the mechanism of dislocation. ${ }^{2}$ In the frequently seen spontaneous dislocations, yawning, laughing, eating, vomiting, singing, which lead to the extreme opening of the mouth, constitute the mechanism of dislocations. ${ }^{1,13-15}$ Even though it is infrequent, iatrogenic TMJ dislocation occurs during dental treatment applications, laryngoscopy, orotracheal intubation, bronchoscopy, or endoscopy. ${ }^{16-22}$ Additionally, maxillofacial traumas might also result in TMJ dislocation. ${ }^{13-15}$ We did not encounter any data on the ratio of these triggers in the literature. In our cases, $98.50 \%$ of primary admission cases were non-traumatic and the most frequent trigger of dislocation was yawning as seen in $80.30 \%$. Only 1 case had a history of trauma. We did not encounter a dislocation caused by iatrogenic reasons. The presence of a healthcare staff trained to perform reductions at the scene of the injury in iatrogenic TMJ dislocations might eliminate the ED visit necessity for the patient; therefore explain the lack of such cases in our study. The evaluation of the recurring admissions in our study reveals that dislocation after eating was also frequent besides yawning. All recurring cases were spontaneous in our study. In the literature, seizure, tetanus infection, and use of drugs such as antipsychotics, which might cause dystonic reactions are also listed as triggers. ${ }^{23-24}$ Three of our primary admission cases also suffered dislocation after a seizure. The seizure was also the trigger in 4 readmitted cases.

The diagnosis of TMJ dislocations is based on medical history and physical examination. In acute dislocations, radiologic imaging is recommended to confirm the diagnosis. ${ }^{7}$ In case of trauma, radiographic evaluation should be made to confirm fractures. In the literature, it was indicated that radiographic evaluation was not required frequently in the management of TMJ dislocations. We did not encounter the rate of radiographic evaluations of such cases in the literature. Our study demonstrated a need for radiography in $13.60 \%(n=9)$ of primary admission cases and detected only one recurring case with imaging. 
The treatment of TMJ dislocations is decided according to the nature of dislocation. In acute dislocations, the frequently applied conservative treatment comprises pain relief with analgesics and manual reduction. ${ }^{1}$ Conventional non-operative manual reduction methods were defined for the treatment of acute dislocations. ${ }^{15}$ Bimanual intraoral traction technique, which was first used by Hippocrates and reached our time with modifications, is used frequently for acute dislocations. We did not encounter sufficient data on successful outcomes of manual reductions for TMJ dislocations in the literature. Our study demonstrated that manual reduction was performed in all cases, but 1 case with fracture. Only in 1 case, the reduction was unsuccessful. In all readmission cases, reduction outcomes were successful.

The secondary reflex contraction in the lateral pterygoid muscle caused by a painful join capsule might impede manual reduction. ${ }^{1}$ Thus, auriculotemporal nerve block or intraarticular injection of local anesthetic before reduction improves reduction success and patient comfort. Systemic sedo-analgesia is also another application recommended for reduction. ${ }^{25}$ We also did not encounter sufficient data on the ratios of sedo-analgesia and local anesthesia used for TMJ dislocation reduction. In our cases, systemic sedo-analgesia was used for $21.20 \%$ $(n=14)$ of primary admission cases and for only 1 readmitted case. Local anesthesia was not used in any of our cases.

In conclusion, early diagnosis and proper treatment of TMJ dislocations are essential for airway safety, pain control, and eating. Even though ED physicians rarely encounter TMJ dislocations, they need to recognize them and to know the treatment options to secure patient comfort and joint function. Our study demonstrates that the ED physicians are capable and successful in non-operative manual reduction applications and patient management in TMJ dislocations for which medical history and physical examination are pillars. The recurring cases frequently presented to the ED should not be disregarded and they should be referred to the relevant clinics for definitive treatment.

Besides, the fact that sedo-analgesia and imaging need is low and reduction success is high when performed with the appropriate technique supports that this application can be performed in primary health care institutions. Therefore, selected patients will not need to be referred to an advanced center.

\section{Limitations}

The retrospective approach of our study might be regarded as a limitation. The information on pain levels, the anatomical direction of joint dislocation (anterior, posterior, superior, or lateral), manual reduction methods, and follow-up evaluations after the ED treatment applications was not found in the record system, thus they could not be included in the study. 


\section{Ethical considerations}

The study was approved by the local ethics committee (24.11.2020/07).

\section{Conflict of interest}

The authors declare no conflict of interest. 


\section{References}

1. Sharma NK, Singh AK, Pandey A, Verma V, Singh S. Temporomandibular joint dislocation. Natl J Maxillofac Surg. 2015 Jan-Jun;6(1):16-20 (doi: 10.4103/0975-5950.168212).

2. Papoutsis G, Papoutsi S, Klukowska-Rötzler J, Schaller B, Exadaktylos AK. Temporomandibular joint dislocation: a retrospective study from a Swiss urban emergency department. Open Access Emerg Med. 2018 Oct 30;10:171-6 (doi: 10.2147/OAEM.S174116).

3. Pillai S, Konia MR. Unrecognized bilateral temporomandibular joint dislocation after general anesthesia with a delay in diagnosis and management: a case report. J Med Case Rep. 2013;7:243.

4. Oliphant R, Key B, Dawson C, Chung D. Bilateral temporoman-dibular joint dislocation following pulmonary function testing: a case report and review of closed reduction techniques. Emerg Med J. 2008;25(7):435-6.

5. Gorchynski J, Karabidian E, Sanchez M. The "syringe" technique: a hands-free approach for the reduction of acute nontraumatic temporo-mandibular dislocations in the emergency department. J Emerg Med. 2014;47(6):676-81.

6. El Bouazzaoui A, Labib S, Derkaoui A, Adnane Berdai M, Bendadi A, Harandou M. Dislocation of temporomandibular joint - an uncommon circumstance of occurrence: vaginal delivery. Pan Afr Med J. 2010;5:23.

7. Schraga D. Reduction of Mandibular Dislocation [Internet]. https://emedicine.medscape.com/article/823775-overview (Date of access: 22.12.2020).

8. Kai S, Kai H, Nakayama E, et al. Clinical symptoms of open lock position of the condyle. Relation to anterior dislocation of the temporomandibular joint. Oral Surg Oral Med Oral Pathol 1992; 74:143.

9. Tocaciu S, McCullough MJ, Dimitroulis G. Surgical management of recurrent TMJ dislocation-a systematic review. Oral Maxillofac Surg. 2019 Mar;23(1):35-45 (doi: 10.1007/s10006-019-00746-5).

10. Myrhaug H. A new method of operation for habitual dislocation of the mandible; review of former methods of treatment. Acta Odontol Scand. 1951 Sep;9(3-4):247-60 (doi:10.3109/00016355109012789).

11. Güven O. Management of chronic recurrent temporomandibular joint dislocations: a retrospective study. J Craniomaxillofac Surg. 2009 Jan;37(1):24-9 (doi: 10.1016/j.jcms.2008.08.005).

12. Nakashima M, Yano H, Akita S, et al. Traumatic unilateral temporomandibular joint dislocation overlooked for more than two decades. J Craniofac Surg. 2007 Nov. 18(6):1466-70.

13. Shorey CW, Campbell JH. Dislocation of the temporomandibular joint. Oral Surg Oral Med Oral Pathol Oral Radiol Endod 2000;89:662.

14. Whiteman PJ, Pradel EC. Bilateral temporomandibular joint dislocation in a 10-month-old infant after vomiting. Pediatr Emerg Care 2000;16:418. 
15. Liddell A, Perez DE. Temporomandibular joint dislocation. Oral Maxillofac Surg Clin North Am $2015 ; 27: 125$.

16. Bhandari S, Swain M, Dewoolkar LV. Temporomandibular joint dislocation after laryngeal mask airway insertion. The Internet J of Anaesth. 2008;16:1-4.

17. Lipp M, Von Domarus H, Daublender M. Temporomandibular joint dysfunction after endotracheal intubation. Anaesthetisa. 1987;36:442-5.

18. Rastogi Nk, Vakharia N, Hung OR. Perioperative anterior dislocation of the temporomandibular joint. Anesth Analg. 1997;84:924-6.

19. Rosemore J, Nikoomanesh P, Lacy BE. Bilateral temporomandibular joint dislocation after PEG tube placement. Gastrointest Endosc. 2004;59:146-7.

20. Kepron W. Bilateral dislocations of the temporomandidibular joint complicating fibreoptic bronchoscopy. Chest. 1986;90:465.

21. Gambling DR, Ross PL. Temporomandibular joint subluxation on induction of anesthesia. Anesth Analg 1988; 67:91.

22. Lacy PD, Lee JM, O'Morain CA. Temporomandibular joint dislocation: an unusual complication of upper gastrointestinal endoscopy. Am J Gastroenterol 2000; 95:3653.

23. Amsterdam JT. Oral medicine. In: Rosen's Emergency Medicine: Concepts and Clinical Practice, Marx JA, Hockberger RS, Walls RM (Eds), Elsevier Saunders, Philadelphia 2014. p.895.

24. Thachil RT, Philip B, Sridhar CB. Temporomandibular dislocation: a complication of tetanus. J Trop Med Hyg 1993; 96:60.

25. Mendez DR, Ness G. Temporomandibular joint (TMJ) dislocation [Internet]. https://www.uptodate.com/contents/temporomandibular-joint-tmj-dislocation (Date of access: 22.12.2020). 